\title{
Roman Jakobson and the topic of translation: Reception in academic reference works
}

\author{
Elin Sütiste \\ Department of Semiotics, University of Tartu \\ Tiigi St. 78-310, Tartu 50410, Estonia \\ e-mail: elin.sytiste@ut.ee
}

\begin{abstract}
The article describes and analyses connections established between Roman Jakobson's scholarly legacy and the topic of translation in a selection of academic reference works. The aim in doing so is twofold: first, to look beyond the conventionalised image of Jakobson as an influential scholar for several disciplines, such as translation studies, linguistics and semiotics, and to provide an overview of the actual reception of his ideas on the level of general academic knowledge as presented by scholarly reference works in these fields. Another aim is to find out whether and how Jakobson's ideas on translation are seen to relate to his other ideas concerning language and communication. It appears that — while there also exist some differences fieldwise as well as among individual reference works - the general reception of Jakobson is based predominantly on just two of his articles (out of his overall legacy of several hundred works) and to a large extent ignores the inner logic of Jakobson's thought as it manifests in his different works (i.e. there are few connections made between his ideas expressed in his different works).
\end{abstract}

\section{Introduction}

Roman Jakobson seems to have had a somewhat uncanny ability to predict some future developments of the sciences he was involved or interested in. At the Symposium on Structure of Language and its Mathematical Aspects in the year 1960 Jakobson made the following statement: "Besides encoding and decoding, also the procedure of recoding, code switching, briefly, the various facets of translation, is becoming one of the focal concerns both of linguistics and of 
communication theory" (Jakobson 1971 [1961]: 576). This statement proved to be prophetic, to the point that about a decade after Jakobson's pronouncement there emerged a special field for studying the "various facets of translation" - modern translation studies.

Jakobson has acquired the status of a highly influential scholar for many disciplines, including linguistics, semiotics, as well as translation studies; there have been written volumes discussing and elaborating Jakobson's works. However, on the first glance it seems that surprisingly little has been written on how Jakobson's general views on language and communication relate to his ideas on translation which could be relevant for a better understanding of Jakobson's contribution to all the fields concerned.

The aim of the present article is to test this impression and to describe and analyse connections established between Jakobson and the topic of translation, focusing on a selection of works that by their definition strive for a balanced, wide and full coverage of a subject articles in academic reference works ${ }^{1}$. Since the primary interest behind this article is to find out whether and how Jakobson's ideas on translation are seen to relate to his other ideas concerning language and communication, the focus here is on articles dealing with Jakobson and translation in encyclopedias representing three disciplines: linguistics, semiotics, and translation studies; my aim has been to consult three encyclopedias from each field.

\section{Overview of the material}

As to the choice of encyclopedias, two principles have been followed: to consult such reference works that (1) are considered representative of the field and (2) are comparable with respect to the time of their publication. Thus, in regard to publication time, all three fields are represented by encyclopedias from 1990s to 2000s. As to the principle of representativeness, the field of translation studies currently offers only two general and comprehensive encyclopedic reference works Baker (1998) and Kittel et al. (2004). Due to this, the aim of con-

1 These are mostly encyclopedias, although among actual titles there are also two "international handbooks" and one "encyclopedic dictionary". For the sake of brevity, in the following I will refer to all of them as "encyclopedias". 
sulting three encyclopedias from the field cannot be met in translation studies. In semiotics, general reference works are not very numerous either; of these Sebeok (1994 [1986]), Bouissac (1998), and Posner et al. (1997-2004) have been chosen here on the grounds that these works are well established in the field and although being composed under the supervision of one or more editors, the articles have been written by an extensive group of contributors (for instance, Winfried Nöth's excellent Handbook of Semiotics (1995) has been left aside on the grounds that it represents essentially one man's view of the discipline). Of the three fields, linguistics is the most established and this is accordingly reflected also in the large number of reference works ranging from student-oriented one-volume works to scholarly multivolume publications. Of this variety, three works of several volumes have been chosen for the present article: Bright (1992), Asher (1994), and Brown (2006).

With regard to encyclopedias of linguistics and semiotics, the procedure was to locate articles written on Roman Jakobson and articles written on the topic of translation, and the next step was to ascertain which of these articles relate Jakobson and the topic of translation, i.e., which articles on Jakobson contain mentions of the topic of translation, and which articles on translation contain references to Jakobson. The data are displayed in the tables below.

Table 1 presents the data for linguistics encyclopedias.

Table 1. Number of articles on Roman Jakobson (R.J.) and on the topic of translation (TR; in white cells on the left side), articles relating Jakobson and the topic of translation (in grey cells on the right side), and articles not relating Jakobson and the topic of translation (in the right end column of the table) in linguistics encyclopedias.

\begin{tabular}{|l|c|c|c|c|c|c|c|}
\hline LINGUISTICS & $\begin{array}{c}\text { On } \\
\text { R.J. }\end{array}$ & $\begin{array}{c}\text { On } \\
\text { TR }\end{array}$ & Total & $\begin{array}{c}\text { On R.J. } \\
\text { incl. TR }\end{array}$ & $\begin{array}{c}\text { On TR } \\
\text { incl. R.J. }\end{array}$ & $\begin{array}{c}\text { Relating } \\
\text { R.J. \& TR }\end{array}$ & $\begin{array}{c}\text { Not relating } \\
\text { R.J. \& TR }\end{array}$ \\
\hline Bright 1992 & 1 & 1 & 2 & 0 & 0 & 0 & 2 \\
\hline Asher 1994 & 1 & 11 & 12 & 0 & 4 & 4 & 8 \\
\hline Brown 2006 & 2 & 17 & 19 & 0 & 1 & 1 & 18 \\
\hline Total & 4 & 29 & 33 & 0 & 5 & 5 & 28 \\
\hline
\end{tabular}


As is shown in the Table 1, in Bright's (1992) encyclopedia of linguistics there is 1 article on Jakobson (abbreviated as "R.J." in the table) and 1 article on the topic of translation (abbreviated as "TR" in the table), but neither does the article on Jakobson contain any mention of the topic of translation (referred to as "art-s on R.J. incl. TR" in the table) nor does the article on translation contain any mention of Jakobson (referred to as "art-s on TR incl. R.J." in the table). In Asher's (1994) encyclopedia there is 1 article on Jakobson and 11 articles on translation; among the latter, there are 4 that also mention Jakobson and thus relate the two subjects. In Brown's (2006) encyclopedia there are 2 articles on Jakobson (more precisely, one is on Jakobson's theory of sign) and 17 articles on the topic of translation. Among the latter there is one that mentions also Jakobson. To sum up: in all three linguistics encyclopedias, of the 4 articles focusing on Jakobson none contain any references to the topic of translation, and among the 29 articles focusing on the topic of translation there are all together 5 that contain references to Jakobson. Among the three linguistics encyclopedias there is one (Bright's) that does not connect Jakobson and the topic of translation at all. ${ }^{2}$ In other words, of the total 33 articles that could, in principle, connect Jakobson and the topic of translation, the majority - 28 articles - do not do that. Only a small segment, 5 articles (about one-seventh or $15 \%$ of all the articles) connect the two subjects. Later below, a closer look will be taken at these 5 articles that make a connection between Jakobson and the topic of translation.

Table 2 shows the data for semiotics encyclopedias.

In Sebeok's (1994 [1986]) encyclopedic dictionary, there is 1 article on Jakobson (that also mentions the topic of translation) and 1 article on the topic of translation (that also mentions Jakobson). Bouissac's (1998) encyclopedia contains 2 articles on Jakobson (more precisely, one is focused on Jakobson's model of communication) and none on the topic of translation. Neither of the 2 articles on Jakobson mentions the topic of translation. The handbook by Posner et al. (1997-2004) contains 1 article on Jakobson (that also contains a mention of the topic of translation) and 1 article on the topic of translation (making reference also to Jakobson). Thus, among the

2 Of course, this conclusion applies only within the limits of articles observed here. 
three semiotics encyclopedias there is one (Bouissac's) that does not make any connection between Jakobson and the topic of translation; furthermore, this encyclopedia does not contain any entry on the topic of translation at all. On the contrary, the other two semiotics encyclopedias (Sebeok's and Posner's) contain articles on translation as well as on Jakobson, with both articles on translation referring also to Jakobson, and both articles on Jakobson referring also to the topic of translation. All together, of the 6 articles that could, in principle, connect Jakobson with the topic of translation, two-thirds (or 66\%) take this opportunity. Later below, a closer look will be taken at the 4 articles in semiotics encyclopedias that make a connection between Jakobson and the topic of translation.

Table 2. Number of articles on Roman Jakobson (R.J.) and on the topic of translation (TR; in white cells on the left side), articles relating Jakobson and the topic of translation (in grey cells on the right side), and articles not relating Jakobson and the topic of translation (in the right end column of the table) in semiotics encyclopedias.

\begin{tabular}{|l|c|c|c|c|c|c|c|}
\hline SEMIOTICS & On R.J. & On TR & Total & $\begin{array}{c}\text { On R.J. } \\
\text { incl. TR }\end{array}$ & $\begin{array}{c}\text { On TR } \\
\text { incl. R.J. }\end{array}$ & $\begin{array}{c}\text { Relating } \\
\text { R.J. \& } \\
\text { TR }\end{array}$ & $\begin{array}{c}\text { Not } \\
\text { relating } \\
\text { R.J. \& TR }\end{array}$ \\
\hline Sebeok 1994 & 1 & 1 & 2 & 1 & 1 & 2 & 0 \\
\hline Bouissac 1998 & 2 & 0 & 2 & 0 & 0 & 0 & 2 \\
\hline $\begin{array}{l}\text { Posner } \text { et al. } \\
\text { 1997-2004 }\end{array}$ & 1 & 1 & 2 & 1 & 1 & 2 & 0 \\
\hline \multicolumn{1}{|r|}{ Total } & 4 & 2 & 6 & 2 & 2 & 4 & 2 \\
\hline
\end{tabular}

Table 3 presents the data for translation studies encyclopedias.

While in encyclopedias of linguistics and semiotics Jakobson and translation form just two topics among a great variety of subjects, in the case of translation studies encyclopedias the situation is somewhat different as all articles deal by definition with the topic of translation. Thus it can be said that all 112 articles in Baker's (1998) encyclopedia and all 106 articles in the handbook by Kittel et al. (2004) deal with the topic of translation. There are no articles dedicated specifically to Jakobson in neither reference work; however, 11 articles in Baker's encyclopedia and 24 articles in the handbook by Kittel et al. contain 
references to Jakobson. In other words, of the total of 218 articles in the two translation studies encyclopedias all together 35 or about onesixth $(16 \%)$ connect Jakobson with the topic of translation. Later below more attention will be paid to these 35 articles in translation studies encyclopedias that connect Jakobson with the topic of translation.

Table 3. Number of articles on Roman Jakobson (R.J.) and on the topic of translation (TR; in white cells on the left side), articles relating Jakobson and the topic of translation (in grey cells on the right side), and articles not relating Jakobson and the topic of translation (in the right end column of the table) in translation studies encyclopedias.

\begin{tabular}{|l|c|c|c|c|c|c|c|}
\hline $\begin{array}{l}\text { TRANSLATION } \\
\text { STUDIES }\end{array}$ & On R.J. & On TR & Total & $\begin{array}{c}\text { On R.J. } \\
\text { incl. TR }\end{array}$ & $\begin{array}{c}\text { On TR } \\
\text { incl. R.J. }\end{array}$ & $\begin{array}{c}\text { Relating } \\
\text { R.J. \& } \\
\text { TR }\end{array}$ & $\begin{array}{c}\text { Not } \\
\text { relating } \\
\text { R.J. \& TR }\end{array}$ \\
\hline Baker 1998 & 0 & 112 & 112 & 0 & 11 & 11 & 101 \\
\hline Kittel et al. 2004 & 0 & 106 & 106 & 0 & 24 & 24 & 82 \\
\hline Total & 0 & 218 & 218 & 0 & 35 & 35 & 183 \\
\hline
\end{tabular}

To sum up what has been said so far: of the three sets of encyclopedias, semiotics encyclopedias, although containing the least number of articles on the topic of translation ( 2 articles), has the largest percentage $(66 \%)$ of articles that connect Jakobson and the topic of translation.

Neither linguistics nor translation studies encyclopedias contain such articles on Jakobson that would also refer to the topic of translation. However, both sets of encyclopedias have articles on translation, including a small section of such (15-16\%) that also mention Jakobson. Table 4 brings together the general data in all three sets of encyclopedias. 
Table 4. The overall number of articles on Jakobson and on the topic of translation (left-hand column), articles connecting Jakobson with the topic of translation (middle column), and articles not connecting the two subjects (right-hand column) in linguistics, semiotics, and translation studies encyclopedias.

\begin{tabular}{|c|c|c|c|}
\hline & $\begin{array}{l}\text { Total No of } \\
\text { art-s on R.J. } \\
\text { and/or on TR }\end{array}$ & $\begin{array}{c}\text { Total No of } \\
\text { art-s relating } \\
\text { R.J. \& TR }\end{array}$ & $\begin{array}{l}\text { Total No of } \\
\text { art-s not relating } \\
\text { R.J. \& TR }\end{array}$ \\
\hline LINGUISTICS & 33 & 5 & 28 \\
\hline SEMIOTICS & 6 & 4 & 2 \\
\hline \begin{tabular}{|l} 
TRANSLATION \\
STUDIES \\
\end{tabular} & 218 & 35 & 183 \\
\hline Total & 257 & 44 & 213 \\
\hline
\end{tabular}

Thus, it can be said that in the three sets of encyclopedias, of all the articles on Jakobson that could in principle refer also to the topic of translation and of all the articles on translation that could in principle refer also to Jakobson (all in all 257 articles), the great majority (213 articles, that is $83 \%$ ) do not connect the two topics and only a fairly small segment (44 articles, that is $17 \%$ ) does that. In the following discussion, only the last portion, that is, only the articles where some kind of connection is made between Jakobson and the topic of translation will be examined more closely. This also means that out of the initial three reference works in linguistics and semiotics, now only two encyclopedias are left from either field. Linguistics is represented by the total of 5 encyclopedia articles, semiotics by 4 , and translation studies by 35 articles in which some relation between Jakobson and the topic of translation has been established.

\section{Connections between Jakobson and} the topic of translation in linguistics encyclopedias

In this section, a closer look will be taken at the details and nature of connections established between Jakobson and the topic of translation in linguistics encyclopedias. Summary of this data is presented in Table 5 . 


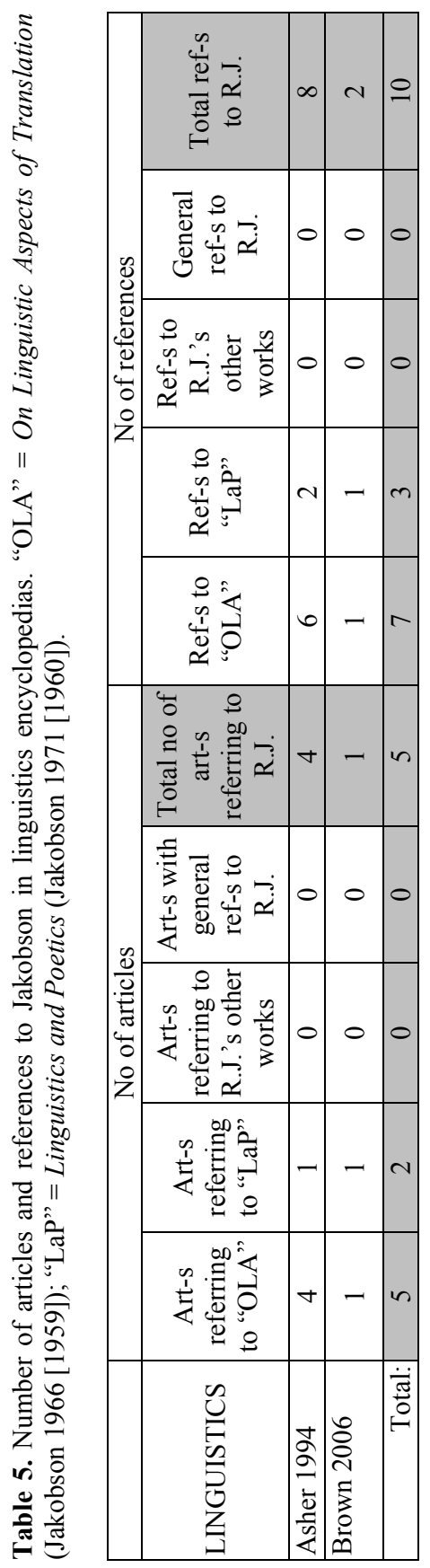


The left side of the table shows how many articles in the linguistics encyclopedias connect Jakobson and the topic of translation, and the right side of the table shows how many times such a connection is made. ${ }^{3}$ This means that, for example, in one encyclopedia article there may occur more than one reference and to more than one work of Jakobson (which also explains why the numbers on the left side of the table need not add up).

The 5 articles that make a connection between Jakobson and translation are all from among those that focus on the topic of translation, not on Jakobson; 4 of them are from Asher's (1994) encyclopedia, 1 from Brown's (2006) encyclopedia. In these 5 articles, Jakobson's name comes up in total 10 times; all these 10 references and allusions ${ }^{4}$ are made in relation to Jakobson's two articles: On Linguistic Aspects of Translation (Jakobson 1966 [1959]; abbreviated as "OLA" in Table 5; all together 7 references) and Linguistics and Poetics (Jakobson 1971 [1960]; abbreviated as "LaP" in Table 5; all together 3 references). There are no other references to Jakobson or to any of his other works. As can be seen in Table 5 , the majority of connections ( 8 out of 10 ) established between Jakobson and the topic of translation are made in the 4 articles of Asher's encyclopedia (1994), and most of these connections are related to references to Jakobson's article On Linguistic Aspects of Translation (6 references out of the total 10).

\subsection{References to On Linguistic Aspects of Translation in articles on translation in linguistics encyclopedias}

In the articles on translation in linguistics encyclopedias, Jakobson's work On Linguistic Aspects of Translation is referred or alluded to in the following cases:

3 It needs to be spelled out that the connections between Jakobson and the topic of translation both in the articles examining some topic related to translation and in the articles dedicated to Jakobson's contribution are made mainly via references or allusions to Jakobson's works.

4 Here and in the following I will make a distinction between referring (resp. reference) and alluding (resp. allusion): "allusion" indicates instances where the author of an article mentions and/or describes another author's idea(s) without giving explicit information of the source (even if the source author's name is mentioned). "Reference" implies that the specific source (the work in which the idea referred to can be found) is also included. In the table, for the sake of brevity only the word "references" is used, although this includes allusions as well. 
(a) Recording Jakobson's observation with regard to the nature of interlingual relations and differences among languages (Jakobson 1966 [1959]: 236): “As Jakobson (1959: 236) has cogently pointed out 'languages differ essentially in what they must convey and not in what they may convey,' and this characteristic is of cardinal importance in translation". - 1 reference (Catford 1994: 4743). ${ }^{5}$

(b) While describing Walter Benjamin's ideas on translation, alluding to Jakobson's idea that poetry is by definition untranslatable (Jakobson 1966 [1959]: 238). One example: "[...] 'poetic principle' which prompted Jakobson to say that only creative transposition, not translation was possible where 'poetic art' is concerned" (Hyde 1994: 4729). — 2 allusions (Hyde 1994: 4728, 4729).

(c) When discussing the topic of equivalence, alluding to Jakobson's treatment of the saying "Traduttore, traditore" (Jakobson 1966 [1959]: 238): "But as translatability is effected by attempts at equivalence, one can only judge its limits through Roman Jakobson's exegesis of the tag, Traduttore, traditore: what are the values the translator is forced to betray in a given text." - 1 allusion (Kelly 1994: 4681).

(d) Referring to Jakobson's distinction between three kinds of translation (Jakobson 1966 [1959]: 233):

Translation is thus characterized as 'interlingual translation' or 'translation proper.' This can be clearly distinguished from 'intralingual translation' or 'rewording' ('interpretation of verbal signs by means of other signs in the same language') and from 'intersemiotic translation' or 'transmutation' that is, 'interpretation of verbal signs by means of signs of nonverbal sign systems' (Jakobson 1959: 233). (Wilss 1994: 4751)

- 1 reference (Wilss 1994: 4751).

(e) Referring to Jakobson's concept of "equivalence in difference" (Jakobson 1966 [1959]: 233-234). One example:

5 Where possible, actual quotes from articles showing the connection between Jakobson and the topic of translation will be included. However, due to the limits of space, in the case of longer discussions my resumes will be provided instead. 
Creativity is presumably a combination of original transfer strategies in one or more translation-relevant textual domains, coupled with a seasoned feeling for contextually determined 'dynamic equivalence' in Nida's (1964) sense or 'equivalence in difference' in Jakobson's (1959) sense. (Wilss 1994: 4750)

— 2 references (Wilss 1994: 4750; Malmkjær 2006: 414-415).

To sum up, the topics in Jakobson's article On linguistic aspects of translation referred to in the articles of linguistics encyclopedias include

(1) Jakobson's view on the question of translatability, especially with regard to the dominance of the 'poetic principle' (3 allusions);

(2) One of Jakobson's central topics throughout his oeuvre invariance in variance, here in the form of 'equivalence in difference' (2 references);

(3) Jakobson's often-quoted observation that the differences among languages with respect to what they must express are greater than differences with regard to what they may express (1 reference); and

(4) Jakobson's distinction between three kinds of translation (1 reference).

\subsection{References to Linguistics and Poetics in articles on translation in linguistics encyclopedias}

In linguistics encyclopedias, 3 connections out of the total 10 between Jakobson and the topic of translation are established via references to Jakobson's article Linguistics and Poetics, which is referred or alluded to in the following instances:

(a) In connection with discussing literary translation, alluding to Jakobson's concept of 'poetic principle' (Jakobson 1971 [1960]: 358). One example:

His [= Sapir's - E. S.] interesting confusion is very germane to literary translation, since it may be described as a structuralist reading of 'parole' as if it were 'langue.' By means of a process rather like Jakobson's 'poetic function' $[\ldots]$ the principle of equivalence has been shifted from the axis of selection to the axis of combination [...]. (Hyde 1994: 4729) 
— 2 allusions (both at Hyde 1994: 4729).

(b) Mentioning Jakobson's model of communication (Jakobson 1971 [1960]: 353) when discussing the dimensions of communication that the translator needs to be aware of: "His [= Nida's $-E$. S.] list of components of the communicative act is strongly reminiscent of Jakobson's enumeration of the factors involved in verbal communication (Jakobson, 1960: 66) [...]". — 1 reference (Malmkjær 2006: 412).

Although there are only three mentions of one of Jakobson's most famous works Linguistics and Poetics in the articles of linguistics encyclopedias, they evoke the two ideas that have been central in drawing so much attention to this article:

(1) Jakobson's concept of poetic function (2 allusions), and

(2) his model of communication (1 reference).

\subsection{Summary: connections between Jakobson and the topic of translation in linguistics encyclopedias}

The connections between Jakobson and the topic of translation in linguistics encyclopedias can be summed up as follows:

(a) In linguistics encyclopedias, there are all together 5 articles that contain in total 10 references/allusions to Jakobson. In these 5 articles, Jakobson himself is nowhere the figure of focus; his ideas are paid attention to in the context of discussing some other issue.

(b) The 5 articles in linguistics encyclopedias refer/allude to two of Jakobson's works: On Linguistic Aspects of Translation (1966 [1959]) and Linguistics and Poetics (1971 [1960]).

(c) Jakobson's contributions that have been judged relevant to refer/ allude to in relation to translation include

(1) the poetic function and its influence on translatability (5 references/allusions);

(2) the issue of 'equivalence in difference' in communication (2 references);

(3) the observation with regard to the differences among languages: what they must express and what they may express (1 reference);

(4) Jakobson's communication model (1 reference); and 
(5) the distinction between three kinds of translation (1 reference).

Half of the references/allusions (5 out of 10) deal with the issues of (the translatability of) texts in which poetic function is dominant. In sum, it can be said that although only two works (albeit of central importance) of Jakobson's extensive oeuvre have been used, the references/allusions in the 5 articles do not focus on just one or two ideas but instead give a rather broad overview of Jakobson's contribution.

\section{Connections between Jakobson and the topic of translation in semiotics encyclopedias}

In this section, a closer look will be taken at the details and nature of connections established between Jakobson and the topic of translation in semiotics encyclopedias. Summary of this data is presented below in Table 6.

Among the 4 articles (data on the articles is presented on the left side of Table 6) that make a connection between Jakobson and the topic of translation, 2 focus on Jakobson (Waugh, Rudy 1998; Eco 1994) and the other 2 focus on the topic of translation (Lambert, Robyns 2004; Schogt, Toury, Niklas 1994). In the articles focusing on the topic of translation, there are all together 9 references to Jakobson (data on the references is presented on the right side of Table 6). In the articles focusing on Jakobson but bringing up also the topic of translation, there are all together 8 references to his works in the contexts of discussing translation-related issues (in other words, articles focusing on Jakobson deal with a variety of topics besides translation but references to Jakobson's works in these contexts are not taken into account here). While there is in total only 1 reference to Jakobson's article Linguistics and Poetics, all 4 articles make at least 2 references each to On Linguistic Aspects of Translation, and 3 articles out of 4 refer also to some other Jakobson's works. There are no such general or unspecified references to Jakobson's ideas whose source would be difficult to identify. All in all in these 4 articles connections between Jakobson and the topic of translation are made 17 times, of which more than half (9 out of 17) are related to his article On Linguistic Aspects of Translation. 


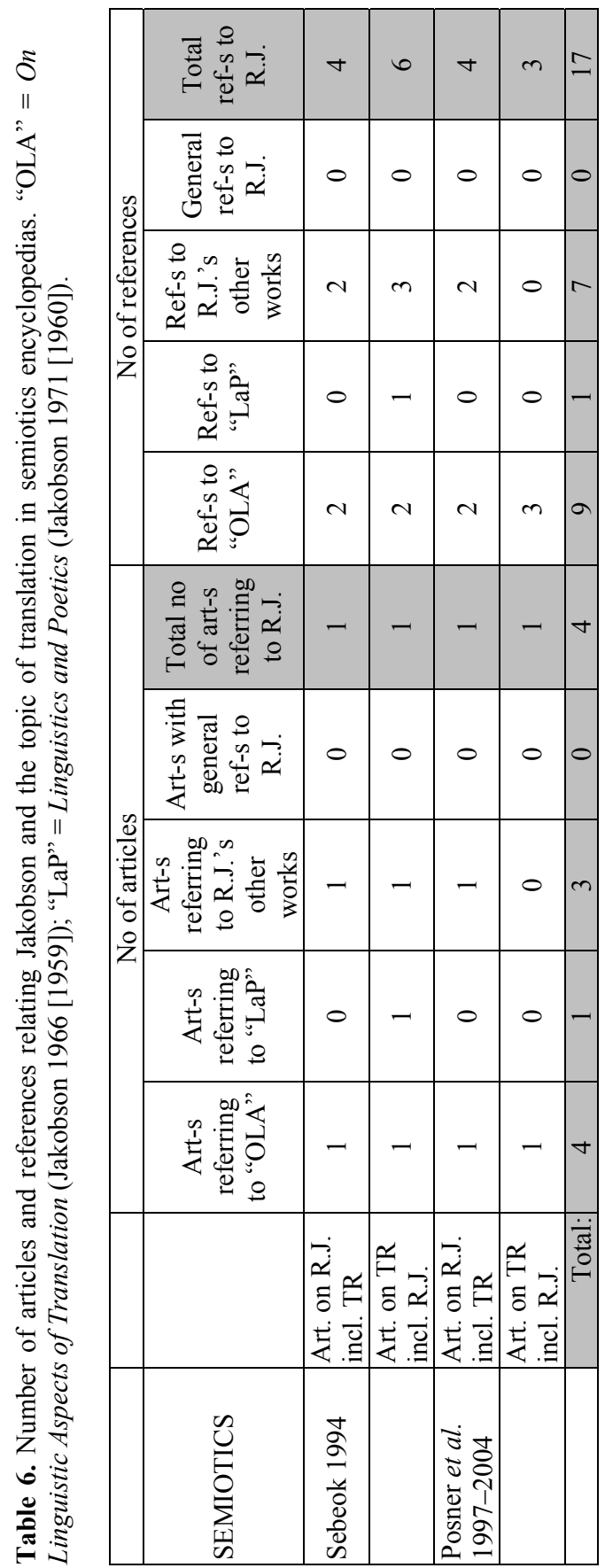




\subsection{References to On Linguistic Aspects of Translation in articles on Jakobson and translation in semiotics encyclopedias}

In the encyclopedia articles focusing on Jakobson, On Linguistic Aspects of Translation is referred to in the following cases:

(a) Pointing out Jakobson's inspiration in Charles S. Peirce's notion that the essence of a sign is its interpretation, that is, translation by some further sign, which in other words means that translation is regarded as an essential aspect of semiotic activity, since signatum of a sign is that which is interpretable, translatable and can be regarded as Peircean interpretant (Jakobson 1966 [1959]: 232233). One example: "[...] Jakobson demonstrates that to interpret a semiotic item means to 'translate' it into another item [...] and that this translation is always creatively enriching the first item (1959), this continuous creativity being the main result of Peirce's "unlimited semiosis'." (Eco 1994: 407). - 3 references (one at Eco 1994: 407, two at Waugh, Rudy 1998: 2262).

(b) In the context of explaining Jakobson's general views on the nature of sign, referring to his distinction between three kinds of translation (Jakobson 1966 [1959]: 233):

\footnotetext{
He [...] insisted that a widened definition of translation - as the interpretation of one sign by another - was an essential aspect of semiotic activity: intralingual translation (paraphrasing), interlingual (translation proper), and intersemiotic (transmutation from one semiotic system to another) [...]. (Waugh, Rudy 1998: 2262)

- 1 reference (Waugh, Rudy 1998: 2262).
}

In the encyclopedia articles focusing on translation as their topic, On Linguistic Aspects of Translation is referred/alluded to in the following cases:

(a) Discussing (in most cases with some criticism) Jakobson's distinction between three kinds of translation (Jakobson 1966 [1959]: 233). One example: "When considering seriously Roman Jakobson's distinctions between various concepts of translation, we need to add several further distinctions [...]" (Lambert, Robyns 2004: 3600). - 2 allusions (both at Lambert, Robyns 2004: 3600), 2 references (Lambert, Robyns 2004: 3604; Schogt, Toury, Niklas 1994: 1113). 
(b) Pointing to Jakobson's (report of Boas') observation that the degree of translatability is lower when translating into a system that makes a certain obligatory differentiation from a system that does not make it than vice versa (Jakobson 1966 [1959]: 235236). - 1 reference (Schogt, Toury, Niklas 1994: 1115).

Those articles in semiotics encyclopedias that focus on Jakobson refer to his article On Linguistic Aspects of Translation foremost in connection with discussing

(1) Jakobson's views on sign and meaning (3 times); but also

(2) Jakobson's distinction between three kinds of translation (1 reference).

On the other hand, the articles that focus on translation refer/allude most to

(1) Jakobson's distinction between three kinds of translation (all together 4 times), but also to

(2) Jakobson's discussion of the issue of translatability between languages with significant differences in their grammatical structures (1 reference).

\subsection{References to Linguistics and Poetics in articles on Jakobson and translation in semiotics encyclopedias}

In the 4 articles in semiotics encyclopedias that connect Jakobson and the topic of translation, Linguistics and Poetics is briefly referred to only once (in an article focusing on the topic of translation), with regard to the concept of communicative-linguistic functions (Jakobson 1971 [1960]: 353). The reference is made in the context of discussing various types of translation processes and the impact that different text-types may have on translation process: "The only thing that may be said to remain invariant is the basic communicative-linguistic functions (e.g. Jakobson 1960), and even this does not go without its problems" - 1 reference (Schogt, Toury, Niklas 1994: 1118). 


\subsection{Other references to Jakobson in semiotics encyclopedias}

Besides references/allusions to On Linguistic Aspects of Translation and Linguistics and Poetics, 3 articles out of 4 (one article focusing on the topic of translation, two focusing on Jakobson) in semiotics encyclopedias refer also to some other work of Jakobson's (all together 7 works). The references are made in the following contexts:

(a) Discussing Jakobson's general understanding of linguistic meaning (referring to Co je poesie? originally published in 1934 ${ }^{6}$ ), especially as based on Peirce's notion of sign, including the view of meaning of a sign as Peirce's interpretant (referring to Jakobson, Fant, Halle 1988 [1952], Preliminaries to Speech Analysis), as that what is interpretable or translatable into a further sign (referring to Jakobson 1985 [1977], A Few Remarks on Peirce, Pathfinder in the Science of Language, p. 251), and Jakobson's view of Peircean approach as "the only sound basis for a strictly linguistic semantics" (referring to Jakobson 1985 [1976], Metalanguage as a Linguistic Problem, p. 118). - 4 references to Jakobson's various works (two at Waugh, Rudy 1998: 2262; two at Eco 1994: 407).

(b) Commenting on Jakobson's observations on the varying degrees of explicitness of information in different languages (referring to Jakobson 1971 [1939], Signe zéro ${ }^{7}$ ) with regard to translation: "Jakobson (1966b) points out that it is more difficult to start from the undifferentiated language, because it does not give the necessary clues to make the compulsory choice in the target language." - 1 reference (Schogt; Toury; Niklas 1994: 1109).

(c) Pointing out Jakobson's notion of communication which encompasses semiotics, so that "communication of any messages" equals semiotics (with the corollary dependence of the term translating on the definition of communication - referring to Jakobson 1971 [1969], Linguistics in Relation to Other Sciences, p. 666):

If "communication" is regarded on its face value, that is, as requiring intention on the part of the addresser, then a communication approach reduces the reference of the term translating in its general sense. If, however, communication encompasses semiotics, so that "communication of messages" equals it (e.g., Jakobson 1971j: 666), then the communication terms are (more or

What is poetry? (Jakobson 1981 [1934]).

The zero sign. 
less) tantamount to the semiotic ones, thus interchangeable and translatable into them. (Schogt, Toury, Niklas 1994: 1115)

- 1 reference (Schogt, Toury, Niklas 1994: 1115).

(d) Making use of Jakobson's distinction between the 'acoustic aspect' (that is heard and has therefore intersubjective, social significance) and 'articulation' (i.e. the production, the 'motor phenomenon' that is merely a physiological prerequisite of the acoustic phenomenon) of sound (reference to Jakobson 1978, Six Lectures on Sound and Meaning, p. 5-6). Toury uses these terms metaphorically to describe his view of translations as foremost facts of the receptor system, which gives them their functional identity and in a way conditions their coming into being. - 1 reference (Schogt, Toury, Niklas 1994: 1121).

To sum up, those 2 articles in semiotics encyclopedias that focus on Jakobson refer to his works (other than On Linguistic Aspects of Translation and Linguistics and Poetics) in connection with the nature of sign and meaning - and by extension thus also translation (all 4 references).

In the one article focusing on translation, references to other works of Jakobson are made in the contexts of (1) discussing translation difficulties as related to differences among languages (1 reference); (2) using communication terms in describing the process of translating (1 reference); (3) describing — and promoting — a shift in the way translations have been studied (1 reference).

All together, articles in semiotics encyclopedias refer to 9 of Jakobson's works (including On Linguistic Aspects of Translation, Linguistics and Poetics as well as other works) in connection with the topic of translation.

\subsection{Summary: connections between Jakobson and the topic of translation in semiotics encyclopedias}

The connections between Jakobson and the topic of translation in semiotics encyclopedias can be summed up as follows:

(a) In semiotics encyclopedias there are all together 4 articles that make a connection between Jakobson and the topic of translation in total 17 times. 
(b) The 4 articles in semiotics encyclopedias refer/allude to in total 9 works by Jakobson: On Linguistic Aspects of Translation (Jakobson 1966 [1959]), Linguistics and Poetics (Jakobson 1971 [1960]), Co je poesie? (Jakobson 1981 [1934]), Signe zéro (Jakobson 1971 [1939]), Preliminaries to Speech Analysis (Jakobson, Fant, Halle 1988 [1952]), Linguistics in Relation to Other Sciences (Jakobson 1969), Metalanguage as a Linguistic Problem (Jakobson 1985 [1976]), A Few Remarks on Peirce, Pathfinder in the Science of Language (Jakobson 1985 [1977]), Six Lectures on Sound and Meaning (Jakobson 1978).

(c) Those articles that focus on Jakobson, not on the topic of translation, all speak of Jakobson's notions of sign and meaning as being intimately related to translation (the view inspired by Peirce), making up more than a third of all references ( 7 out of 17). The topic of sign and meaning was important for Jakobson and appeared in several of his works; in semiotics encyclopedias there are references to 5 articles with regard to this topic.

(d) Articles that focus on translation connect Jakobson with the topic of translation foremost via Jakobson's distinction between three kinds of translation (all together 4 times), while there is only 1 reference to this distinction in an article on Jakobson. This supports the impression that in Jakobson's overall legacy this distinction does not come forth as one of his top significant contributions while in the context of discussions on translation, this tripartition is one of Jakobson's central additions to the field. At the same time, in the 2 articles on translation (Schogt, Toury, Niklas 1994 and Lambert, Robyns 2004) this distinction is discussed at greater length than in most other encyclopedia articles and is also subjected to criticism.

(e) In addition to the above, in articles focusing on translation, Jakobson and the topic of translation are connected by making use of Jakobson's terms and ideas when

(1) Discussing the issue of translatability in the case of languages with different grammatical structures (2 references);

(2) Approaching translation process in general communication terms (1 reference);

(3) Regarding translations as forming a semiotic system of their own (1 reference);

(4) Mentioning Jakobson's functions of communication (1 reference). 
All in all it can be said that in those articles (in semiotics encyclopedias) whose focus is Jakobson himself, the topic of translation is touched upon mostly in relation to Jakobson's notion of sign and meaning; in other words, translation is seen as a semiotic mechanism. The only reference to the distinction between three kinds of translation in an article on Jakobson is also related to his overall widened definition of translation as an essential aspect of semiotic activity. In articles where translation is the central topic, Jakobson is most referred to in connection with his distinction between three ways of interpreting a verbal sign, but also with regard to some of his ideas on language and the interrelations between languages, not emphasizing specifically the semiotic basis of his thinking.

\section{Connections between Jakobson and the topic of translation in translation studies encyclopedias}

In this section, a closer look will be taken at the details and nature of connections established between Jakobson and the topic of translation in translation studies encyclopedias. Summary of this data is presented below in Table 7 .

In the two translation studies encyclopedias, there are no articles dedicated specifically to Jakobson; references to him are made in the context of discussing other topics. In the two encyclopedias, there are in total 35 articles (data on the articles is on the left side of Table 7) in which all together 58 references/allusions are made to Jakobson (data on the references and allusions is presented on the right side of the table). 11 articles (with the total of 22 references) are from Baker's encyclopedia (1998), 24 articles (with the total of 36 references) are from the handbook by Kittel et al. (2004). Two-thirds of all the articles (23 out of the total 35) refer to Jakobson's On Linguistic Aspects of Translation, making up half of all the references (29 out of 58). A quarter of all the references (14 out of 58) in the total of 11 articles are to Linguistics and Poetics, the greater share of these (11) being provided by Kittel et al. (2004). There are 3 articles in which all together 5 references are made also to Jakobson's other works, and there are 8 articles in which all together 10 general or unspecified references to Jakobson are made. 


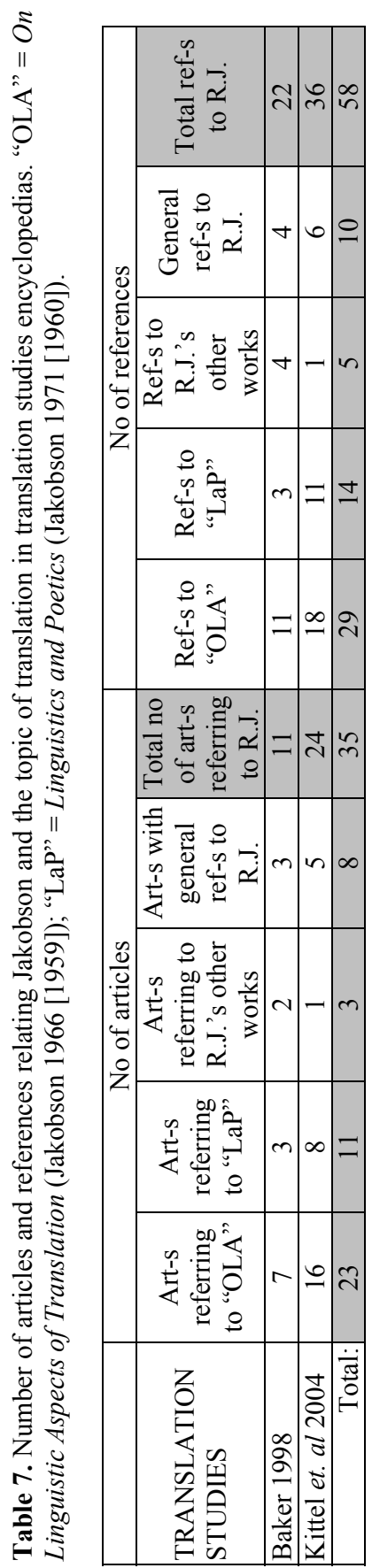




\subsection{References to On Linguistic Aspects of Translation in translation studies encyclopedias}

The article On Linguistic Aspects of Translation is referred/alluded to in the following cases:

(a) Discussing or mentioning Jakobson's distinction between three kinds of translation (Jakobson 1966 [1959]: 233), implying a widened definition of translation as such. For example:

I know of no research that looks specifically at the phenomena of intralingual or intersemiotic translation. We do have classifications like Jakobson's, which alert us to the possibility of such things as intersemiotic and intralingual translation, but we do not make any genuine use of such classifications in our research. (Baker 1998: xvii)

- 2 allusions (Baker 1998: xvii; Robinson 1998: 183) and 10 references (Eco, Nergaard 1998: 219-220; Pym, Turk 1998: 275; Gorlée 2004: 55; Henschelmann 2004: 390; Hermans 2004b: 196; Lenschen 2004: 430; Mueller-Vollmer 2004: 151; Schäffner 2004: 107; Schreiber 2004: 273; Van Gorp 2004: 63).

(b) Referring to the notion of "equivalence in difference" formulated by Jakobson (1966 [1959]: 233-234). One example:

Roman Jakobson (1959) is largely in favour of translatability because he sees translation as operating within languages as well as between them (and between different semiotic systems): 'equivalence in difference' is thus described as the basic problem 'of every language' [...]. (Pym; Turk 1998: 275)

- 3 references (Pym, Turk 1998: 275; Henschelmann 2004: 390; Lewandowska-Tomaszczyk 2004: 304).

(c) Pointing to Jakobson's view that language in its general mode (that is, on its 'cognitive level') allows (and even requires) translation (Jakobson 1966 [1959]: 234). One example:

Es wird also zwischen Übersetzbarkeit im denotativen und im konnotativen Bereich unterschieden. Dort, wo Sprache in denotativer Funktion auftritt, wird die Möglichkeit der Übersetzbarkeit uneingeschränkt bejaht. [...] (Auch für Jakobson 1959, 234 gilt: 'All cognitive experience and its classification is conveyable in any existing language.'). (Koller 2004: 189)

Distinction is thus made between translatability with respect to the denotative and with respect to the connotative range. In cases where language in denotative function arises, the possibility of translatability is affirmed without 
reservation. [...] (This also applies to Jakobson 1959, 234: 'All cognitive experience and its classification is conveyable in any existing language.') 8

- 2 references (Brotherston 1998: 211; Koller 2004: 189).

(d) Recording Jakobson's views on interlingual relations and translatability (Jakobson 1966 [1959]: 236). One example:

It [= Jakobson's dynamic translatability $-E$. S.] also hinges on a dynamic view of natural languages as evolving entities: for Jakobson, 'languages differ essentially in what they must convey and not in what they can convey' (ibid.: 264). (Pym; Turk 1998: 275)

- 4 references (Schreiber 2004: 270; Gémar 2004: 741; two at Pym; Turk 1998: 275).

(e) Referring to Jakobson's view of poetry (or the sphere of the dominance of the poetic function, as in the case of pun) as being "by definition untranslatable" and requiring therefore "creative transposition" (Jakobson [1959]: 238). One example:

As a form of complex and self-conscious discourse, both exploiting and exposing the verbal medium it uses to the hilt, wordplay has often been seen as a paradigm of poetic language: "The pun [...] reigns over poetic art, and whether its rule is absolute or limited, poetry by definition is untranslatable" (Jakobson 1959, 238). (Delabastita 2004b: 602)

- 4 references (Delabastita 2004a: 872; Delabastita 2004b: 602; two at Connolly 1998: 171).

(f) Referring to the article in general (not explicating any exact segment or idea in the article because of which it is being mentioned). Two examples:

During this early period, the overall orientation was also largely pedagogical, with few - if any - descriptive studies and little or no attempt at developing theoretical models (Jakobson 1959 is a notable exception). (Baker 2004: 288);

Originally, scholarly interest in translation was actually more of a sideline cherished by disciplines that had been firmly established in the academe long before translation studies made their first academic appearance in the middle of the twentieth century. Among them philosophers [...], and more recently linguists (Brower 1959/1966; Jakobson 1959/1966 [...] concerned themselves with aspects of translation. (Neubert 2004: 229).

- 4 references (Gentzler 1998: 168; Baker 2004: 288; Chesterman 2004: 94; Neubert 2004: 229).

8 Here and in the following, translations from German are mine - E. S. 
To sum up, the topics in Jakobson's article On Linguistic Aspects of Translation referred to in the articles of translation studies encyclopedias include

(1) Jakobson's distinction among three kinds of translation (12 references out of the total 29);

(2) Jakobson's views on the issue of translatability (translatability as a normal condition of communication within and between languages, which at the same time does not need to be "total" translatability - hence also Jakobson's notion of "equivalence in difference" ( 9 references);

(3) Jakobson's views on poetry/poetic function, which appears as an exception to the general translatability postulate (4 references);

(4) General references to the article On Linguistic Aspects of Translation (4 references).

These general references try to give an overall idea of the article, to set it in context, and to relate Jakobson's contribution in it to other disciplines and other approaches to translation prevalent at the time of the article's publication.

\subsection{References to Linguistics and Poetics in translation studies encyclopedias}

The article Linguistics and Poetics is referred to in the following cases:

(a) Mentioning Jakobson's model of communication or some aspect of it: (some or all six) factors of communication or functions of language (Jakobson 1971 [1960]: 353, 357). One example: "The author's communicative intention is closely related to text functions - e.g. referential, expressive, conative, phatic and poetic (Jakobson 1966).” (Švejcer 2004a: 240). — 1 allusion (Hermans 2004a: 124) and 3 references (Mason 1998: 32; Švejcer 2004a: 240; Švejcer 2004b: 382).

(b) Discussing Jakobson's view of poetry and specifically poetic function or the concept of "poeticalness" (Jakobson 1971 [1960]: 356ff). For example:

The pun "projects the principle of equivalence [...] from the axis of selection into the axis of combination", thereby "promoting the palpability of signs" and "deepening the fundamental dichotomy of signs and objects" (Jakobson 
1967, 302-3), fully satisfying Jakobson's famous description of the poetic function. (Delabastita 2004b: 601-602)

- 8 references (Albrecht 2004: 247-248; Delabastita 2004a: 872; Delabastita 2004b: 601-602, 602; Nikula 2004: 663; three references at Gorlée 2004: 56).

(c) Referring to the article in its entirety as an example of Jakobson's and his colleagues' effort at "isolating and cataloguing, in a variety of languages, the specific formal features that distinguish literary expressions from normal ones" (Gentzler 1998: 168) and as an example of "how a structurally-oriented close textual analysis can also account for stylistic choices" (Eco; Nergaard 1998: 219). — 2 references (Gentzler 1998: 168; Eco; Nergaard 1998: 219).

The references made in translation encyclopedias to Jakobson's article Linguistics and Poetics can be regarded as forming two large sets:

(1) Centring around Jakobson's notions of "poeticalness" or "poetic function", whether explicitly (as in quoting Jakobson's definition of "poetic function") or mentioning issues related to it (such as literary expressions, stylistic choices) (10 references out of 14);

(2) Referring to Jakobson's communication model, in most cases foregrounding his distinction between different language functions (4 references).

\subsection{Other references to Jakobson in translation studies encyclopedias}

In addition to On Linguistic Aspects of Translation and Linguistics and Poetics, all together 5 references (out of the total 58) in 3 articles (out of 35) are made to Jakobson's other works:

(a) Referring to Jakobson's article Co je poesie? (Jakobson 1981 [1934]) as an example of Jakobson being a representative of Russian Formalism and Czech structuralism, whose one aim was the distinguishing of literary expressions from 'ordinary' ones. 1 reference (Gentzler 1998: 168).

(b) Emphasising Jakobson's work in poetics and his early contribution to theory of poetry translation: 
Demands by members of the Prague School around 1929 for elaborating the principles of a synchronic description of poetic language [...] were already being addressed in a number of important publications by Roman Jakobson (1896-1982), including "O cheshskom stikhe"9 and "Základy českého verše" $[\ldots]$. In parallel with the development of a structural theory of poetic language, attempts were also made to develop a theory of the translation of poetry. [...] Among other significant studies in this area, mention should be made of Jakobson's essay “O překladu veršǔu" ". (Kufnerová 1998: 380)

-3 references (all at Kufnerová 1998: 380).

(c) Mentioning Jakobson's work co-written with Morris Halle, Fundamentals of Language (Jakobson, Halle 1956):

It has been generally agreed, though, that the tropes at the centre of the figural space are metaphor, metonymy and synecdoche. They are related and connected, although the relations and connections are not completely clear. Jakobson and Halle (1956) claim that synecdoche is reducible to metonymy. (Pisarska 2004: 522)

- 1 reference (Pisarska 2004: 522).

All these 5 references to Jakobson's works other than On Linguistic Aspects of Translation and Linguistics and Poetics relate to his work on poetics, verse and poetic language, among them one reference to his early work on verse translation.

Besides references to one or another particular work of Jakobson, there are also as many as 10 references (in all together 8 articles) to Jakobson or his ideas in general, that is, none of his works is mentioned specifically:

(a) Emphasising Jakobson's work in poetics. One example: "Their [= Augusto and Haroldo de Campos' - E. S.] view of translation privileges form over content and favours the introduction of new forms into the target language. For these views, they draw on Walter Benjamin, Roman Jakobson and Ezra Pound." (Barbosa; Wyler 1998: 332). — 2 references (Gentzler 1998: 168; Barbosa; Wyler 1998: 332).

9 O cheshskom stikhe = "О чешском стихе - преимущественно в сопоставлении с русским" (On Czech verse, mainly in comparison with Russian Jakobson 1979 [1923]).

${ }_{10}$ Základy českého verše (Prague: Odeon, 1926) or Foundations of Czech verse is a revised version of Jakobson 1979 [1923].

11 On the translation of verse (Jakobson 1979 [1930]). 
(b) Sketching briefly the significance of Jakobson's contribution to translation studies against its context: "Traditionally, translation scholars (pre-Jakobson) attempted to imagine and define what literary translations should be." - 1 reference (Gentzler 1998: $167)^{12}$.

(c) Showing Jakobson's (among others) significance for some theories in translation studies: "In the early 1970s, Itamar Even-Zohar, a scholar from Tel Aviv, developed the polysystem model on the basis of his work on Hebrew literature. Its roots, however, lie in the writings of the late Russian Formalists Jurij Tynjanov, Roman Jakobson and Boris Ejkhenbaum." - 1 reference (Shuttleworth 1998: 176).

(d) Presenting Jakobson as an important thinker on language and an influential figure in the history of semiotics and linguistics. Two examples:

A sign possesses the characteristic ability not only to represent meaningfully something else, [...] but also to be decoded, understood and interpreted as such. This is merely another way of stating the Scholastic aliquid stat pro aliquo (something stands for something else) formula [...], which has been used as a definition of the semiotic sign from Augustine to Roman Jakobson. (Gorlée 2004: 54)

It $[=$ the question of the possibility of transfer $-E$. $S$.] has been posed by every serious translator and thinker on language from Dante to Luther, from Erasmus and Dryden to Proust [...], from Horace to Walter Benjamin and Roman Jakobson. (Steiner 2004: 3)

- 4 references (Gorleé 2004: 54; Steiner 2004: 3; LewandowskaTomaszczyk 2004: 304; Mueller-Vollmer 2004: 142).

(e) Pointing to and explaining the structuralist approach to translation. One example:

Translation "may be broken down into a doing interpretive of the ab quo text and a doing productive of the ad quem text" (Greimas/Courtès [1979] 1982, 352). Saussure's binary oppositions [...], Louis Hjelmslev's dichotomies [...], Jakobson's binarism (code/message, selection/combination, metaphor/metonymy) and Yury Lotman's distinctions [...] are reconstructed into a literal sense, which becomes a structure, which is never equivalent. (Gorlée 2004: 57)

12 Although no specific reference is given here, it can be assumed that the allusion is to Jakobson's article On Linguistic Aspects of Translation as this is usually considered to contain his main contribution to translation studies. 
-2 references (Gorlée 2004: 57; Weitemeier 2004: 889).

The 10 references that point to Jakobson in general and not specifically to any one of his works show the extent to which the knowledge of Jakobson, his works and main ideas is presupposed by the authors of these articles. Some of the total 10 references point to Jakobson's lifelong preoccupation with questions of poetics and indicate his innovative approach to describing literary translations, some emphasise Jakobson's importance as a thinker on language and related issues, whereas others are a bit more specific and refer to some of Jakobson's more well-known ideas (e.g. "equivalence in difference") or his general views (e.g. dualism, binarism).

\subsection{Summary: connections between Jakobson and the topic of translation in translation studies encyclopedias}

The connections between Jakobson and the topic of translation in translation studies encyclopedias can be summed up as follows:

(a) In translation studies encyclopedias there are all together 35 articles that make a connection between Jakobson and the topic of translation in total 58 times.

(b) The 35 articles in translation studies encyclopedias refer/allude to in total 7 works of Jakobson: O cheshskom stikhe (Jakobson 1979 [1923]), Základy českého verše (originally published in 1926), O prekladu veršu (Jakobson 1979 [1930]), Co je poesie? (Jakobson 1981 [1934]), Fundamentals of Language (Jakobson, Halle 1956), On Linguistic Aspects of Translation (Jakobson 1959), Linguistics and Poetics (Jakobson 1960).

(c) In these 35 articles, the 58 connections made between Jakobson and the topic of translation take the form of referring or alluding to Jakobson in the contexts of discussing various translation-related topics. Half of all the references (29 out of 58) are to the article $O n$ Linguistic Aspects of Translation, nearly one quarter of all the references (14 out of 58) are to the article Linguistics and Poetics, and the rest 15 references are either to other works or to Jakobson in general.

(d) About one-fifth of all connections between the topic of translation and Jakobson (12 references out of 58) in translation studies encyclopedias is established through references to Jakobson's 
distinction between three kinds of translation - intralingual, interlingual and intersemiotic - set forth in his article On Linguistic Aspects of Translation. Although mentioned more times than any other idea or concept of Jakobson, this tripartition is rarely discussed at any length and is instead referred to rather briefly, in some cases not even spelling out all three possibilities but mentioning only one or two.

(e) Other connections between Jakobson and the topic of translation are developed through two main topics:

(1) Jakobson's views on literary creation, poetics (the sphere of the dominance of the poetic function; all together 19 references); and

(2) His principal views on language (including his concept of linguistic sign, model of communication, and concept of "equivalence in difference"; all together 13 references).

Both of these large topics are manifested in various ways, and references to these are made in order to illuminate some issues either relating to the questions of general translatability of natural languages or more generally various semiotic systems, or relating to the questions of translatability in texts with the predominant poetic function.

There are 4 references to the article On Linguistic Aspects of Translation which do not specify why exactly the article is being mentioned, but which nevertheless also connect Jakobson with the topic of translation. In addition, a rather large part of all the references (10 out of the total 58) to Jakobson is formed by such references that do not mention any of his works or even ideas in particular, but presume the reader's familiarity with the person and his contribution. Most of these unspecified references present Jakobson as a major figure in the history of linguistics or point to his contributions in the study of poetics.

\section{Conclusions}

In the encyclopedias of linguistics, semiotics, and translation studies, connections between Jakobson and the topic of translation - both in the articles examining some topic related to translation and in the articles dedicated to Jakobson and his contribution - are established 
via references or allusions to Jakobson, his ideas and works. Because of this, the task of this article formulated as the description and analysis of the connections between these two subjects becomes in most cases rephrased as the reception of Jakobson's ideas with regard to the topic of translation. In the three sets of encyclopedias, there appear some similarities but also differences with respect to which aspects and works of Jakobson's overall legacy are considered relevant for the topic of translation.

\section{Main topics and viewpoints}

In general, there appear to be three main topics that form the basis for creating connection between Jakobson and the issue of translation in the encyclopedia articles considered here:

(1) Jakobson's distinction between three kinds of translation,

(2) his views on language in general, and

(3) his views on language use with the predominant poetic function.

However, in different encyclopedias there appear some differences with regard to the specific topics chosen as relevant from among Jakobson's oeuvre for discussions on translation.

In linguistics encyclopedias, the topic of translation is approached mainly through Jakobson's views on poetics and language: half of the references have to do with (the translatability) of texts with the predominant poetic function; other references are mostly related to questions of features of (natural) languages that enable or affect their translatability.

In translation studies encyclopedias, about one-fifth of all connections between Jakobson and the topic of translation is established through references to his distinction between three kinds of translation. Although mentioned more times than any other idea or concept of Jakobson, references to this tripartition are generally rather brief and sometimes even fragmentary (i.e., do not mention all three possibilities but only one or two of them). Other connections between Jakobson and the topic of translation are developed through two main topics: Jakobson's views on such language use where the poetic function is predominant (and its effects on translation) and some of his principal views on language. 
One feature that distinguishes articles in translation studies encyclopedias from those in linguistics and semiotics encyclopedias are general, unspecified references to Jakobson in which no specific work or idea of his is mentioned. Such references seem to presuppose the reader's familiarity with the person and his contribution.

In semiotics encyclopedias, the nature of connections established between Jakobson and the topic of translation depends to some extent on whether the article focuses on Jakobson or on the topic of translation. Thus, in articles whose focus is Jakobson, the topic of translation enters the general discussion mainly by way of Jakobson's views on language and communication as semiotic phenomena, especially Jakobson's view of meaning as a semiotic or rather, a translational process. Such references make up more than one-third of all the references to Jakobson in semiotics encyclopedias.

In articles focusing on the topic of translation, Jakobson's name comes up most often in connection with his distinction among three kinds of translation (about one quarter of all connections), including two lengthier treatments and also criticisms of this distinction. In the articles in which the central topic is translation, not Jakobson, semiotic issues are somewhat more on the background, so that there are also a few references to some of Jakobson's ideas on language and the relations between languages without emphasising specifically the semiotic basis of his thinking.

Besides greater emphasis on Jakobson's overall semiotic attitude towards issues of language and meaning, Jakobson's reception in semiotics encyclopedias differs from that in linguistics and translation studies encyclopedias also by the fact that articles in semiotics encyclopedias make use of less ideas in On Linguistic Aspects of Translation, and none of them mentions the problem of poetic translation and creative transposition that is referred to in several articles in linguistics and translation studies encyclopedias. What is the reason behind this? In his article On Linguistic Aspects of Translation Jakobson seems to draw a rather firm line between "ordinary" translation (which mostly refers to metalinguistic operations carried out with regard to the cognitive level of language, in which "language is minimally dependent on the grammatical pattern" - Jakobson 1966 [1959]: 236) and "poetic" translation or creative transposition (which implies such use of language in which grammatical categories "carry a high semantic import" (ibid.) or, in other words, in which the poetic 
function is the dominant function). Since from Jakobson's several works (including Linguistics and Poetics) we know that Jakobson in fact regarded language functions as forming a hierarchy in each act of communication, that is, all factors and functions are at least potentially present in each act of communication, it would lead us to think that Jakobson could not have drawn an absolute and impenetrable line between "ordinary" and "poetic" language use and, by extension, also translation. Although this issue is not explicitly pondered upon in the majority of articles in any encyclopedia studied here, there is one article that briefly comments on this: writing about wordplay translation (in a translation encyclopedia; Kittel et al. 2004), Dirk Delabastita quotes Jakobson's famous line, "Poetry by definition is untranslatable" but goes on to clarify that "Jakobson's argument need not be taken at face value (e.g. one might want to object to its underlying, rather static equivalence-based view of translation and therefore of translatability), but it remains a powerful statement of a widely held conviction" (Delabastita 2004b: 602). Delabastita therefore seems to belong among such readers of Jakobson who do not fall for his (seemingly?) strong polarisation of "ordinary" and "poetic" translation. However, as Delabastita mentions, this polarisation, as expressed also by Jakobson's quote, expresses a "widely held conviction". That this may indeed be so is illustrated by two other, identically worded interpretations of the same line: "[...] it is this fact that lies at the root of Jakobson's resolute belief that poetry is by definition untranslatable" (Hyde 1994: 4728; my emphasis - E. S.) and "Roman Jakobson's resolute belief that poetry is by definition untranslatable [...]" (Connolly 1998: 171; my emphasis — E. S.). Thus, both Hyde's article on literary translation in a linguistics encyclopedia (Asher 1994) and Connolly's article on poetry translation in a translation studies encyclopedia (Baker 1998) display the conviction that Jakobson indeed firmly believed in the irreconcilably opposite nature of "poetic" translation and "ordinary" translation. This interpretation is extended also to another well-known thought expressed by Jakobson: “[...] 'poetic principle' which prompted Jakobson to say that only creative transposition, not translation was possible where 'poetic art' is concerned"' (Hyde 1994: 4729; my emphasis - E. S.) and "Roman Jakobson's resolute belief that poetry is by definition untranslatable led to the [...] approach that only 'creative trans- 
position', rather than translation, is possible where poetic art is concerned" (Connolly 1998: 171; my emphasis - E. S.).

Other articles that also deal with issues pertaining to literary or poetic translation do not foreground the opposition of "poetic" vs. "ordinary" translation - although they do pay attention to the topic of "poeticalness" or the dominance of the poetic function in verbal art (Gentzler 1998; Kufnerová, Osers 1998; Delabastita 2004a; Gorlée 2004; Nikula 2004). It is interesting to note, however, that the question of the specificity of artistic expression with regard to translation is nowhere emphasised in the articles of semiotics encyclopedias (Eco 1994; Schogt, Toury, Niklas 1994; Waugh, Rudy 1998; Lambert, Robyns 2004) - which must be at least partly due to the fact that artistic translation is not the central focus in these articles, but probably also due to the more general tendency of semiotics not to polarise artistic and "ordinary" expressions but to regard these rather as operating on a gradational scale.

\section{"Popular quotes" and other highlights}

Among various references to Jakobson's works and thoughts there stand out a few recurring quotes or quote-like references which seem to have acquired the status of scholarly catch-phrases and which also characterise the three main topics mentioned above. The most "popular" lines are the following:

\footnotetext{
"Equivalence in difference" (reference to Jakobson 1966 [1959]: 233; appears all together 5 times);

"The poetic function projects the principle of equivalence from the axis of selection into the axis of combination" (reference to Jakobson 1971 [1960]: 358; appears 4 times);

"Languages differ essentially in what they must convey and not in what they may convey" (reference to Jakobson 1966 [1959]: 236; appears 3 times);

"Poetry is by definition untranslatable" (reference to Jakobson 1966 [1959]: 238; appears 3 times);

"Only creative transposition", not translation, is possible where poetic art is concerned (reference to Jakobson 1966 [1959]: 238; appears 2 times)
} 
That we are dealing here with indeed popular lines is evidenced not only by their recurrences in different articles, but also by some comments attributed by the authors referring to them. For example:

Auch der häufig angeführte Satz Roman Jakobsons, "The poetic function projects the principle of equivalence from the axis of selection into the axis of combination" [...]" (Nikula 2004: 663; my emphasis — E. S.);

Also the frequently stated sentence of Roman Jakobson [...] "The poetic function projects the principle of equivalence from the axis of selection into the axis of combination" $[\ldots]$ "

"Languages differ essentially in what they must convey and not in what they may convey" [...] - diese oft zitierte Erkenntnis R. Jakobsons ist von zentraler Bedeutung für das Verhältnis von Übersetzung und Interpretation" (Schreiber 2004: 270; my emphasis - E. S.);

"“'Languages differ essentially in what they must convey and not in what they may convey" [...] - this often-quoted insight of R. Jakobson is of central importance for the relationship of translation and interpretation."

As Roman Jakobson [...] has famously argued, the pun epitomizes the poetic function of language [...] (Delabastita 2004a: 872; my emphasis - E. S.).

Expressions like "häufig angeführte" (frequently stated), "oft zitierte" (often quoted) and "famously argued" clearly point to the fact that they characterise some phenomena that are supposed to be familiar to a large audience. Of course, repeating such lines in reference works only adds to their already established fame. However, without a critical stance towards such catch-phrases they run the risk of becoming petrified and unproductive slogans.

In addition to the famous quotes and near-quotes, the encyclopedia articles considered here reflect also the popularity of the tripartite division of translation types and the schemes of communication factors and functions introduced by Jakobson. The terms used by Jakobson (1966 [1959]: 233) for designating three kinds of interpreting a verbal sign - intralingual, interlingual, and intersemiotic translating - appear each approximately 20 times within the body of all articles studied here. Some authors' comments on the tripartition also reflect its status, for example:

A second group of typologies is based on the nature of the code-switch, such as Jakobson's frequently quoted [...] distinction between intralingual, interlingual and intersemiotic translation. (Lambert, Robyns 2004: 3604; my emphasis - E. S.) 
The only typology, which has gained some currency (e.g., Jakobson 1959), has been worked out in terms of the relations (differences and similarities) between the basic types of the two codes [...] (Schogt; Toury; Niklas 1994: 1113; my emphasis - E. S.)

Jakobson's definitions [of three types of translation - E. S.] have long been treated as a point of departure for subsequent discussions of translation. (Eco; Nergaard 1998: 219-220; my emphasis - E. S.)

All current work on intersemiotic translation [...] has its origin in Roman Jakobson's (1896-1982) remarks on the three kinds of 'interpreting a verbal sign' (Gorlée 2004: 55; my emphasis - E. S.)

[...] Jakobson's celebrated semiotic division of three kinds of translation. (Hermans 2004b: 196; my emphasis - E. S.)

While these comments reflect the wide popularity of Jakobson's distinction between three kinds of translation, some of them also criticise it. For example, although Lambert and Robyns (2004: 3604) say the distinction is "frequently quoted", they add that it is also "highly artificial". The typology is also criticised by Toury who points out that "this typology is afflicted with the traditional bias for linguistic translating" and anyhow "such a typology is far from satisfactory" as among other faults it does not take into account the fact that texts are usually organised in several codes, not just one code (Schogt, Toury, Niklas 1994: 1113). Hermans, while speaking of Jakobson's "celebrated semiotic division", refers to and draws on Derrida's (probably almost as famous) critique of this division (Hermans 2004b: 196). Thus, to sum up the attitudes that the encyclopedia articles display towards Jakobson's distinction between three kinds of translation, it is evident that the distinction is widely known and often quoted but at the same time it has also provoked discussion and in some cases also critique.

Jakobson's other very well-known theoretic models are those of communication factors and functions (Jakobson 1960: 353, 357). Apparently since these are not explicitly related to the topic of translation, they are also mentioned much less in the encyclopedia articles considered here, with individual functions getting different amount of attention and with poetic function being the one most often referred to (all together, other functions are each mentioned 3-5 times, poetic function 10 times; if we add to the latter its near-synonyms such as "poeticalness", "poetic principle" etc., the number of 
references is almost doubled). Still, the wide knowledge of Jakobson's communication models can be illustrated by the following example:

The widely used terminology of 'source' and 'target' text betrays a teleological conception of translation, possibly influenced by Roman Jakobson's communication schemata showing a message travelling from a sender to a receiver [...]. (Hermans 2004a: 124; my emphasis - E. S.)

The above quote reflects also the fact that from among many authors starting with Claude Shannon and Warren Weaver who have written on communication and proposed their communication models, it is Jakobson who appears to have been instrumental in introducing this line of thought into humanities, including translation studies.

\section{Jakobson's bibliography}

Of the total 257 articles written either on Jakobson or on the topic of translation in the eight encyclopedias considered here, 213 articles $(83 \%)$ do not make any connection between the two subjects. Some connection is established in $44(17 \%)$ articles out of 257 . Considering the huge variety of issues and names that can be associated with the topic of translation as well as Roman Jakobson's enormous legacy and contributions to so many fields, $17 \%$ seems like a rather large amount. In these 44 encyclopedia articles, there are all in all 87 instances in which some connection between Jakobson and the topic of translation is established, with references or allusions to all together 13 works of Jakobson.

Thus, as can be seen in Table 8, in linguistics encyclopedias there are references to 2 of Jakobson's articles; in semiotics encyclopedias, attention is paid to 9 of Jakobson's works, and in translation studies encyclopedias, there appear references to 7 of Jakobson's works: 


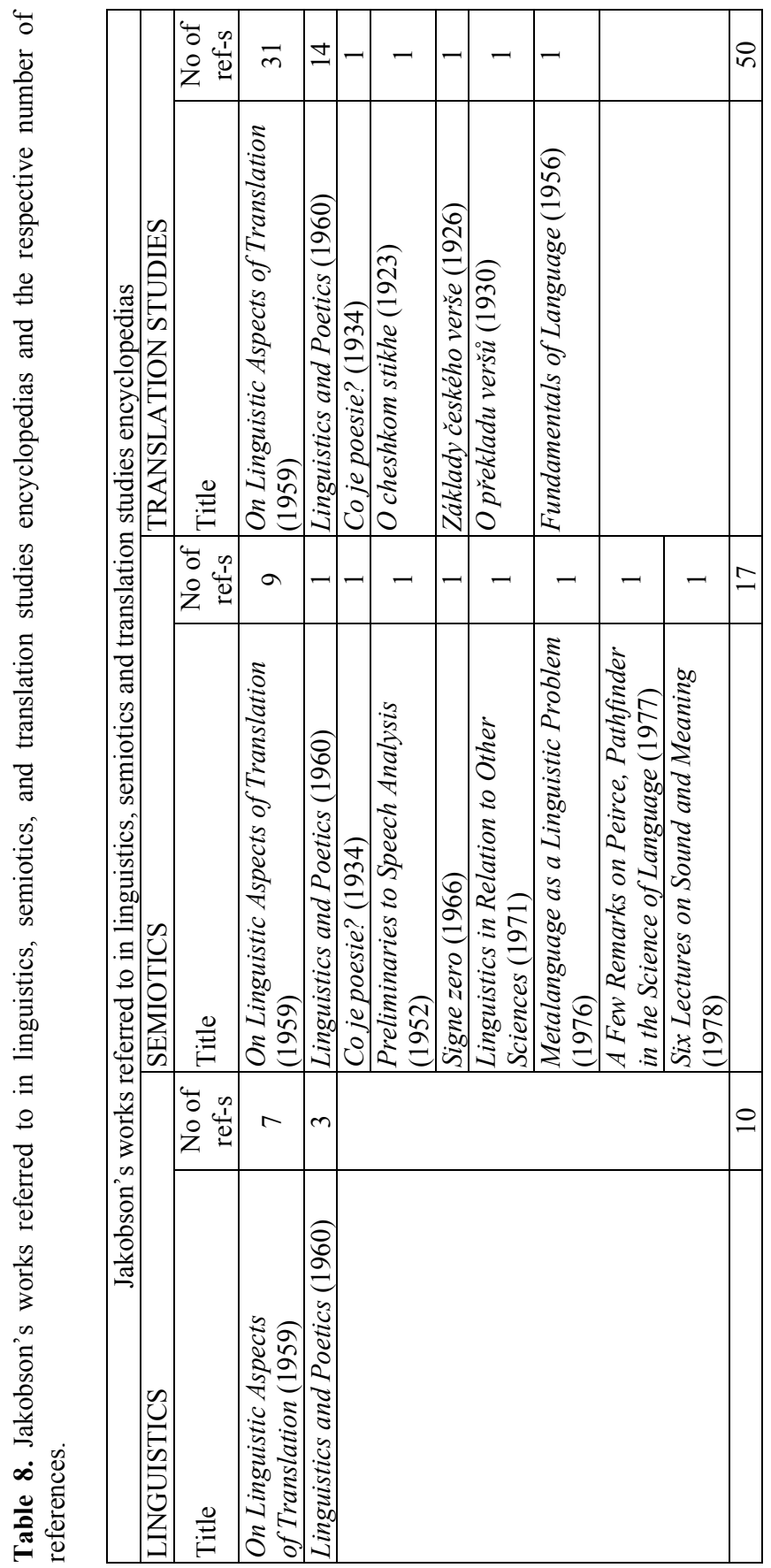


The number of Jakobson's works to which references are made is not in correlation with the number of articles referring to them in one or another set of encyclopedias: while semiotics encyclopedias contain the smallest number of articles (4) in which connections between Jakobson and the topic of translation are made, they include the largest number of works by Jakobson (9). Translation studies encyclopedias contain 35 articles in which Jakobson is related to the topic of translation, yet they refer in total to fewer works by Jakobson (7) than articles in semiotics encyclopedias. Linguistics encyclopedias with their 5 articles in which connections between Jakobson and the topic of translation are established regard only 2 of his works as relevant for discussing translation issues.

The complete bibliography of Jakobson's works (Rudy 1990) lists 686 titles (not including reprints). Thus, the 13 works of Jakobson to which there appear references in the 44 encyclopedia articles considered here, amount to slightly over $2 \%$ of Jakobson's entire legacy of 686 writings.

Over half of all the connections (47 out of 87) between Jakobson and the topic of translation are made via references and allusions to Jakobson's article On Linguistic Aspects of Translation and about one-fifth of all the connections (18 out of 87) are made via references and allusions to the article Linguistics and Poetics. This means that more than two-thirds of Jakobson's entire reception in encyclopedias of linguistics, semiotics, and translation studies (65 references out of 87 are based on the significance attributed to Jakobson's two articles, which makes only $0,3 \%$ of his entire written legacy. Contrary to the general positive impression left by the overall proportion (17\%) of articles making some connection between Jakobson and the topic of translation, this figure - well under $1 \%$ - seems small.

Besides these two most popular works, articles in linguistics and semiotics encyclopedias refer also to 11 other works by Jakobson (all together 12 references), which amounts to $1,6 \%$ of the entire legacy of Jakobson's writings. (In addition to references to specific works of Jakobson, there are 10 connections made between Jakobson and the topic of translation that do not point to any specific work of Jakobson but to him or his ideas in general.)

In other words: nearly nine-tenths of all connections (77 out of 87) between Jakobson and the topic of translation in the encyclopedia articles considered here are made via recourse to Jakobson's 13 works 
that make less than $2 \%$ of his entire written legacy, and the majority of these nine-tenths are made by referring to just two of his works that makes $0,3 \%$ of all of Jakobson's written works.

The last numbers are modest to say the least. Together with the overall impressions left from the present study, they suggest some final conclusions, also for further discussion:

1. Since such a small part of Jakobson's entire legacy is represented in encyclopedia articles considered here, there rises a doubt that they paint a rather limited and superficial picture of Jakobson and his contribution. This doubt is further strengthened by the fact that most of Jakobson's reception relies overwhelmingly on just two of his works, but also by phenomena like "popular quotes" that are repeated from article to article. We are left with an impression that a great part of Jakobson's legacy is not actually used, it is not even really known.

2. At the same time, as encyclopedias are by their nature collections of general knowledge, they cannot be expected to provide very thorough reflections on any subject. Therefore it would be informative to study more closely the reception of Jakobson with regard to his ideas on translation in the body of more specialised academic literature: articles, monographs, collections etc. This would reveal to what extent general academic reference works are representative of the actual scholarly reception of Jakobson.

3. One conclusion of the present study is the confirmation that at least on the level of academic reference works, authors writing about Jakobson's ideas with regard to translation make surprisingly few connections between his ideas expressed in his different works, including his two most popular articles. For instance, except for a couple of instances in which a connection is made between Jakobson's view of poetic function (as discussed in his article Linguistics and Poetics) and poetic translation (regarded as basically impossible and requiring creative transposition instead, as discussed in On Linguistic Aspects of Translation), no encyclopedia article considered here pays further attention to the possible relations between the topics discussed in these Jakobson's two most famous articles; neither is the division of translation types further interpreted in terms of his communication model or vice versa. We are left with an impression that this direction of study has simply remained unexplored, but also that the inner logic 
of Jakobson's overall thought with respect to the topic of translation may also be worthwhile to be examined closer. ${ }^{13}$

\section{References}

Asher, R. E. (ed.) 1994. The Encyclopedia of Language and Linguistics. 10 vols. Oxford, New York, Seoul, Tokyo: Pergamon Press.

Albrecht, Jörn 2004. The different branches of descriptive linguistics and translation. In: Kittel et al. (eds.) 2004: 243-259.

Baker, Mona (ed.) 1998. Routledge Encyclopedia of Translation Studies. London, New York: Routledge.

- 1998. Introduction. In: Baker (ed.) 1998: xiii-xviii.

- 2004. Linguistic models and methods in the study of translation. In: Kittel et al. (eds.) 2004: 285-294.

Barbosa, Heloisa Gonçalves; Wyler, Lia 1998. Brazilian tradition. In: Baker (ed.) 1998: 326-332.

Bouissac, Paul (ed.) 1998. Encyclopedia of Semiotics. New York, Oxford: Oxford University Press.

Bright, William (ed.) 1992. International Encyclopedia of Linguistics. 4 vols. New York, Oxford: Oxford University Press.

Brotherston, Gordon 1998. Script in translation. In: Baker (ed.) 1998: 211-218.

Brown, Keith (ed.) 2006. Encyclopedia of Language \& Linguistics. Second edition. 14 vols. Amsterdam etc.: Elsevier.

Catford, J. C. 1994. Translation: Overview. In: Asher (ed.) 1994: vol. 9, 47384747.

Chesterman, Andrew 2004. Translation as an object of research. In: Kittel et al. (eds.) 2004: 93-100.

Connolly, David 1998. Poetry translation. In: Baker (ed.) 1998: 170-176.

Delabastita, Dirk 2004a. Literary style in translation: Wordplay. In: Kittel et al. (eds.) 2004: 870-874.

- 2004b. Wordplay as a translation problem: A linguistic perspective. In: Kittel et al. (eds.) 2004: 600-606.

Eco, Umberto 1994. Jakobson, Roman (1896-1982). In: Sebeok (ed.) 1994: vol. 1, 402-408.

Eco, Umberto; Nergaard, Siri 1998. Semiotic approaches. In: Baker (ed.) 1998: $218-222$.

Gémar, Jean-Claude 2004. Traduire le langage du droit: langue, droit et traduction. In: Kittel et al. (eds.) 2004: 737-747.

Gentzler, Edwin 1998. Poetics of translation. In: Baker (ed.) 1998: 167-170.

13 Acknowledgement. The work on the present article has been supported by ETF (Estonian Science Foundation) Grant no. 5717, and the project of the Centre of Excellence in Cultural Theory. 
Gorlée, Dinda L. 2004. Translation as a semiotic problem, including intersemiotic translation. In: Kittel et al. (eds.) 2004: 53-61.

Henschelmann, Käthe 2004. Übersetzungsverfahren. In: Kittel et al. (eds.) 2004: 388-406.

Hermans, Theo 2004a. Metaphor and image in the discourse on translation: A historical survey. In: Kittel et al. (eds.) 2004: 118-128.

- 2004b. Translation as an object of reflection in modern literary and cultural studies: Hermeneutics to poststructuralism. In: Kittel et al. (eds.) 2004: 191200.

Hyde, G. M. 1994. Translation, literary. In: Asher (ed.) 1994: vol. 9, 4725-4730.

Jakobson, Roman 1979 [1923]. О чешском стихе - преимущественно в сопоставлении с русским. In: Jakobson, Roman. Selected Writings V: On Verse, Its Masters and Explorers. The Hague: Mouton, 3-130.

- 1979 [1930]. On the translation of verse. In: Jakobson, Roman. Selected Writings V: On Verse, Its Masters and Explorers. The Hague: Mouton, 131134. [English translation by $\mathrm{P}$. and W. Steiner of $O$ prekladu veř̌u (1930).]

- 1966 [1959]. On linguistic aspects of translation. In: Brower, Reuben A. (ed.), On Translation. New York: Oxford University Press, 232-239.

- 1971 [1939]. Signe zéro. In: Jakobson, Roman. Selected Writings II: Word and Language. The Hague: Mouton, 211-219.

- 1971 [1960]. Closing statement: Linguistics and poetics. In: Sebeok, Thomas A. (ed.), Style in Language. Cambridge: The M. I. T. Press, 350-377.

- 1971 [1961]. Linguistics and communication theory. In: Jakobson, Roman, Selected Writings II: Word and Language. The Hague: Mouton, 570-579.

- 1971 [1969]. Linguistics in relation to other sciences. In: Jakobson, Roman. Selected Writings II: Word and Language. The Hague: Mouton, 655-696.

- 1978. Six Lectures on Sound and Meaning. Brighton: Harvester Press. [Translated from the French by John Mepham.]

- 1981 [1934]. What is poetry? In: Jakobson, Roman, Selected Writings III: Poetry of Grammar and Grammar of Poetry. The Hague: Mouton, 740-750. [English translation by M. Heim of "Co je poesie?" (1933-34).]

- 1985 [1976]. Metalanguage as a linguistic problem. In: Jakobson, Roman, Selected Writings VII: Contributions to Comparative Mythology. Studies in Linguistics and Philology, 1972-1982. Berlin: Mouton Publishers, 113-121.

- 1985 [1977]. A few remarks on Peirce, pathfinder in the science of language. In: Jakobson, Roman. Selected Writings VII: Contributions to Comparative Mythology. Studies in Linguistics and Philology, 1972-1982. Berlin: Mouton Publishers, 248-253.

Jakobson, Roman; Fant, C. Gunnar; Halle, Morris 1988 [1952]. Preliminaries to speech analysis: The distinctive features and their correlates. In: Jakobson, Roman, Selected Writings VIII: Major Works, 1976-1980. Berlin: Mouton de Gruyter, 585-660.

Jakobson, Roman; Halle, Morris 1956. Fundamentals of Language. The Hague: Mouton.

Kelly, L. G. 1994. Translatability: Limits. In: Asher (ed.) 1994: vol. 9, 46774682. 


\section{Elin Sütiste}

Kittel, Harald; Frank, Armin Paul; Greiner, Norbert; Hermans, Theo; Koller, Werner; Lambert, José; Paul, Fritz (eds.) 2004. Übersetzung: Ein internationales Handbuch zur Übersetzungsforschung. 1. Teilband. Berlin, New York: Walter de Gruyter.

Koller, Werner 2004. Die Übersetzung als Gegenstand der Sprachwissenschaft. In: Kittel et al. (eds.) 2004: 180-191.

Kufnerová, Zlata; Osers, Ewald 1998. Czech tradition. In: Baker (ed.) 1998: 376382.

Lambert, José; Robyns, Clem 2004. Translation. In: Posner et al. (eds.) 19972004: vol. 4, 3594-3614.

Lenschen, Walter 2004. Die Übersetzung aus älteren Sprachstufen am Beispiel des Deutschen. In: Kittel et al. (eds.) 2004: 430-435.

Lewandowska-Tomaszczyk, Barbara 2004. Semantics and translation. In: Kittel et al. (eds.) 2004: 301-312.

Malmkjær, K. 2006. Approaches to translation, linguistic. In: Brown (ed.) 2006: vol. 1, 409-416.

Mason, Ian 1998. Communicative/functional approaches. In: Baker (ed.) 1998: 29-33.

Mueller-Vollmer, Kurt 2004. Sprachphilosophie und Übersetzung: Das Interesse der Sprachphilosophie an der Übersetzung. In: Kittel et al. (eds.) 2004: 129 155.

Neubert, Albrecht 2004. Translation as a topic of linguistics and text science. In: Kittel et al. (eds.) 2004: 229-235.

Nikula, Henrik 2004. Sprachwissenschaftliche Aspekte der Übersetzung literarischer Texte: Erzählprosa und Verdichtung. In: Kittel et al. (eds.) 2004: 662-668.

Nöth, Winfried 1995 [1990]. Handbook of Semiotics. Bloomington: Indiana University Press.

Posner, Roland; Robering, Klaus; Sebeok, Thomas A. (eds.) 1997-2004. Semiotik. Ein Handbuch zu den zeichentheoretischen Grundlagen von Natur und Kultur. 4 vols. Berlin, New York: Walter de Gruyter.

Pym, Anthony; Turk, Horst 1998. Translatability. In: Baker (ed.) 1998: 273-277.

Robinson, Douglas 1998. Pseudotranslation. In: Baker (ed.) 1998: 183-185.

Rudy, Stephen 1990. Roman Jakobson, 1896-1982: A Complete Bibliography of His Writings. Berlin, New York: Mouton de Gruyter.

Schäffner, Christina 2004. Systematische Übersetzungsdefinitionen. In: Kittel et al. (eds.) 2004: 101-117.

Schogt, Henry G.; Toury, Gideon; Niklas, Ursula 1994. Translation. In: Sebeok (ed.) 1994: vol. 2, 1107-1124.

Schreiber, Michael 2004. Übersetzung und andere Formen der Textverarbeitung und Textreproduktion in sprachwissenschaftlicher Sicht. In: Kittel et al. (eds.) 2004: 268-275.

Sebeok, Thomas A. (ed.) 1994. Encyclopedic Dictionary of Semiotics. 2nd ed. 3 vols. Berlin, New York: Mouton de Gruyter.

Shuttleworth, Mark 1998. Polysystem theory. In: Baker (ed.) 1998: 176-179. 
Steiner, George 2004. Translation as conditio humana. In: Kittel et al. (eds.) 2004: $1-11$.

Švejcer, A. D. 2004a. Possibilities and limitations of linguistic approaches to translation. In: Kittel et al. (eds.) 2004: 236-242.

- 2004b. Translatability with reference to different levels of linguistic description. In: Kittel et al. (eds.) 2004: 376-387.

Van Gorp, Hendrik 2004. Translation and comparable transfer operations. In: Kittel et al. (eds.) 2004: 62-68.

Waugh, Linda R.; Rudy, Stephen R. 1998. Jakobson and structuralism. In: Posner et al. (eds.) 1997-2004: vol. 2, 2256-2271.

Weitemeier, Bernd 2004. Literarischer Stil in der Übersetzung: Epochenstile und Personalstile. In: Kittel et al. (eds.) 2004: 889-898.

Wilss, H. C. Wolfram 1994. Translation: Process and Procedures In: Asher (ed.) 1994: vol. 9, 4747-4756.

\section{Роман Якобсон и перевод: рецепция в академических справочниках}

Статья описывает и анализирует те связи между Романом Якобсоном и темой перевода, которые выявляются в академических справочниках. Цель статьи двоякая: во-первых, рассмотреть повнимательнее ставшее уже штампом представление о Якобсоне как влиятельном ученом в области многих дисциплин, в том числе переводоведения, лингвистики и семиотики, и изучить его реальную рецепцию на уровне академических справочников. Во-вторых, - выяснить, связывают ли вообще и каким именно образом якобсоновское понимание процесса перевода с его взглядами на язык и коммуникацию. Выясняется, что в рамках рассмотренных источников рецепция Якобсона ограничивается в основном двумя статьями (при том, что наследие Якобсона исчисляется несколькими сотнями работ!), и при этом авторы не обращают особого внимания на внутреннюю логику якобсоновской мысли.

\section{Roman Jakobson ja tõlkimine: retseptsioon akadeemilistes teatmeteostes}

Artikkel kirjeldab ja analüüsib seoseid, mida loovad akadeemilised teatmeteosed Roman Jakobsoni ja tõlkimise teema vahel. Artiklil on kahetine eesmärk: esiteks, heita lähem pilk juba stambiks muutunud ettekujutusele Jakobsonist kui mõjukast teadlasest mitmete distsipliinide, sealhulgas tõlketeaduse, keeleteaduse ja semiootika jaoks ning käsitleda 
tema tegelikku retseptsiooni akadeemiliste teatmeteoste tasandil. Teine eesmärk on välja selgitada, kas ja kuidas seostatakse Jakobsoni arusaamu tõlkimisest tema vaadetega keelele ja kommunikatsioonile üldisemalt. Selgub, et - ehkki valdkonniti ja teatmeteoste endi vahel esineb ka erinevusi - vaadeldud teatmeteoste tasandil põhineb Jakobsoni retseptsioon ülekaalukalt tema kahel artiklil (kogu Jakobsoni pärand hõlmab mitusada tööd). Samuti ei pöörata sellel tasandil suuremat tähelepanu Jakobsoni mõtte sisemisele loogikale, see tähendab, vähe võetakse arvesse võimalikke seoseid Jakobsoni erinevates töödes väljendatud ideede vahel. 